\title{
Tuberculosis and HIV coinfection and related collaborative activities in Latin America and the Caribbean
}

\author{
Ralfh Moreno, ${ }^{1}$ Giovanni Ravasi, ${ }^{1}$ Pedro Avedillo, ${ }^{1}$ and Rafael Lopez ${ }^{1}$
}

Suggested citation Moreno R, Ravasi G, Avedillo P, Lopez R. Tuberculosis and HIV coinfection and related collaborative activities in Latin America the Caribbean. Rev Panam Salud Publica. 2020;44:e43. https://doi.org/10.26633/RPSP.2020.43

ABSTRACT Objective. To inform about the most recent epidemiological trends and integrated programmatic response to tuberculosis (TB) and HIV coinfection in Latin America and the Caribbean (LAC).

Methods. A descriptive review analyzed the most relevant indicators on TB/HIV coinfection in 33 countries in LAC with a cross-sectional and time-trend approach. Data were obtained from publicly available databases and analyzed through simple proportions, weighted means, and risk ratios.

Results. In LAC, during 2017, $80.8 \%$ of TB patients were actively screened for HIV, with a $25.6 \%$ increase between 2011 and 2017. In the same year, the proportion of TB patients with HIV-positive status was 11.2\%, with a small but progressive reduction of $5 \%$ since 2011 . The provision of antiretroviral therapy and anti-TB medication among TB/HIV coinfected patients for 2017 was at $60 \%$. Only one-third of people living with HIV had access to isoniazid preventive therapy. Overall, the mortality in the TB/HIV cohort has not changed since 2012, hovering at around $20 \%$.

Conclusions. TB/HIV collaborative activities, as the backbone to address TB/HIV coinfection, are being scaled up in LAC and some indicators show a tendency toward improvement; nevertheless, our review shed light on the need to keep strengthening integration of service delivery, joint monitoring and evaluation, and data quality.

Keywords

HIV; tuberculosis; coinfection; health policy; Latin America.

People living with HIV (PLHIV) are on average 20 times more likely to develop active tuberculosis (TB) (1). In fact, TB accounts for nearly one-third of all AIDS-related deaths globally (2), making it the leading cause of mortality in PLHIV (3). In the same manner, TB and HIV/AIDS are, respectively, the third and fourth leading causes of mortality related to infectious diseases, only behind lower respiratory tract infections and diarrheal diseases (4). Furthermore, these infections share several biological and socioeconomic risk factors that either increase the likelihood of coinfection when one of these pathologies is present, or amplify the damage caused by the other (5-7). Consequently, as stated in the End TB Strategy (8), the Global Health Sector Strategy on HIV 2016-2021 (9), and the
Declaration of the UN General Assembly high-level meeting on the fight against TB (10), program integration and collaborative activities are fundamental for a comprehensive and successful preventive, diagnostic, and therapeutic strategy on TB/HIV coinfection. In this regard, the World Health Organization (WHO)'s Policy on Collaborative TB/HIV Activities (WHO's TB/HIV Policy henceforth) (11) provides a clear set of recommendations with 12 collaborative activities framed under three main objectives since 2004: 1) establish and strengthen the mechanisms for delivering integrated TB and HIV services; 2) reduce the burden of TB in PLHIV and initiate early antiretroviral therapy; and 3) reduce the burden of HIV in patients with presumptive and diagnosed TB.

\footnotetext{
1 Pan American Health Organization, Washington DC, United States of America.

$\triangle$ Ralfh Moreno, ralfmorenog@gmail.com
} 
Although sub-Saharan Africa has the highest TB/HIV burden worldwide (12), the impact of this dual infection cannot be underestimated in Latin America and the Caribbean (LAC), where in 2017, 2.1 million people were living with HIV (3), around 220000 people were notified as having active TB (12), the estimated incidence of TB/HIV was 4.6 per 100000 (12), and the estimated HIV-positive TB deaths were around 5900 (12).

Nonetheless, other than some documents providing general information for the whole Region of the Americas $(12,13)$, only few outdated $(14)$ or partial reports $(15,16)$ illustrating the situation of the TB/HIV coinfection in LAC are available. Thus, the objective of this paper is to provide an updated epidemiological and programmatic analysis on TB/HIV coinfection and the related collaborative activities in LAC. This is with the aim of steering further discussion among health policy makers and other relevant stakeholders to bring about actions to consolidate and expand TB/HIV collaborative activities in LAC countries and foster integration of TB and HIV services.

\section{MATERIALS AND METHODS}

A descriptive review was conducted illustrating the main epidemiological and programmatic metrics regarding TB/HIV coinfection in 33 countries in LAC. These indicators were based on the seven Core Global and National Indicators from WHO's Guide to Monitoring and Evaluation for Collaborative TB/ HIV Activities, 2015 Revision (17). This guide is a supporting document on how to assess the specific objectives and activities recommended in WHO's TB/HIV Policy. In addition, the three main objectives related to cooperation and integration of TB/HIV services from the latter document served as the general framework for discussing the results in this paper. Finally, national policy and service integration indicators on TB/HIV coinfection from the Global AIDS Monitoring framework were included (18).

The information was obtained from two publicly available databases: WHO database on TB (19) and UNAIDS Global AIDS Monitoring database (20). All the above-mentioned information was notified by each country to WHO and UNAIDS through standardized questionnaires. The information used in this review was downloaded in September of 2018 and included notified data spanning from 2011 to 2017. In addition, since all data were aggregated and personal information was not available, ethical approval was not required.

\section{Data analysis}

The review describes the indicators with two different methods. The first is a cross-sectional approach illustrating the last available data point (i.e., 2017 or before) for any given indicator for each country in LAC, as well as an aggregated value (i.e., mean) for the whole region. When applicable, risk ratios (RR) are used. The second approach is a time-trend description of selected key indicators using a mean for LAC for the last seven years or less, depending on data availability. Given the broadly disparate number of cases in each country, all means were weighted, using denominators as the respective benchmark.

Missing data were treated differently depending on the type of data description method. For those indicators described in a cross-sectional manner, observations with missing data or with seemingly inaccurate results (e.g., percentages above 100) were replaced with data from the closest available year. For those indicators described through time-trends, observations with missing data for any year were removed from the analysis. Finally, data were analyzed using Stata ${ }^{\circledR} 14.0$ and Microsoft Excel 15.21.1.

\section{RESULTS}

Although $100 \%$ of LAC countries report having established HIV testing policies in persons with TB, only around $86 \%$ have set up mechanisms to integrate HIV counseling and testing in their TB services as a regular practice (Table 1). Nonetheless, the actual proportion of registered new and relapse TB patients with documented HIV status (TB patients with documented HIV status, indicator A.1) was $80.8 \%$ (Table 2). In relation to this indicator's behavior over time, there was a $25.6 \%$ increase for the whole LAC region between 2011 and 2017, although with a tendency of stagnation at around $80 \%$ during the last three years (Figure 1). In addition, Table 1 shows that the policies related to

TABLE 1. TB/HIV service delivery and integration policies, 2017

\begin{tabular}{|c|c|c|c|c|c|c|c|c|}
\hline $\begin{array}{l}\text { Region } \\
\text { (number of } \\
\text { countries) }\end{array}$ & $\begin{array}{l}\text { HIV testing in } \\
\text { persons with TB }\end{array}$ & $\begin{array}{l}\text { Integration of } \\
\text { HIV counseling } \\
\text { and testing in TB } \\
\text { services }\end{array}$ & $\begin{array}{l}\text { Integration of TB } \\
\text { screening in HIV } \\
\text { services }\end{array}$ & $\begin{array}{l}\text { Preventive therapy } \\
\text { for PLHIV (IPT) }\end{array}$ & $\begin{array}{c}\text { Antiretroviral } \\
\text { therapy provision } \\
\text { in TB clinics }\end{array}$ & $\begin{array}{l}\text { TB treatment } \\
\text { in antiretroviral } \\
\text { therapy settings }\end{array}$ & $\begin{array}{l}\text { TB infection } \\
\text { control in HIV } \\
\text { health care } \\
\text { settings }\end{array}$ & $\begin{array}{l}\text { Integration of ART } \\
\text { and TB treatment }\end{array}$ \\
\hline & $\begin{array}{l}\% \\
(\mathrm{n})\end{array}$ & $\begin{array}{l}\% \\
(n)\end{array}$ & $\begin{array}{l}\% \\
(n)\end{array}$ & $\begin{array}{l}\% \\
(n)\end{array}$ & $\begin{array}{l}\% \\
(n)\end{array}$ & $\begin{array}{l}\% \\
(n)\end{array}$ & $\begin{array}{l}\% \\
(n)\end{array}$ & $\begin{array}{l}\% \\
(n)\end{array}$ \\
\hline Caribbean (16) & $\begin{array}{c}100.0^{\mathrm{a}} \\
(13)\end{array}$ & $\begin{array}{l}76.9^{a} \\
(10)\end{array}$ & $\begin{array}{l}76.9^{a} \\
(10)\end{array}$ & $\begin{array}{l}93.8 \\
(15)\end{array}$ & $\begin{array}{c}40.0^{\mathrm{b}} \\
(6)\end{array}$ & $\begin{array}{l}66.7^{\mathrm{b}} \\
(10)\end{array}$ & $\begin{array}{l}76.9^{a} \\
(10)\end{array}$ & $\begin{array}{l}76.9^{a} \\
(10)\end{array}$ \\
\hline Latin America (17) & $\begin{array}{c}100.0 \\
(17)\end{array}$ & $\begin{array}{l}93.8^{c} \\
(15)\end{array}$ & $\begin{array}{l}94.1 \\
(16)\end{array}$ & $\begin{array}{c}100.0 \\
(17)\end{array}$ & $\begin{array}{l}5.9 \\
(1)\end{array}$ & $\begin{array}{l}70.6 \\
(12)\end{array}$ & $\begin{array}{l}81.3^{c} \\
(13)\end{array}$ & $\begin{array}{l}76.5 \\
(13)\end{array}$ \\
\hline All LAC (33) & $\begin{array}{c}100.0^{\mathrm{e}} \\
(30)\end{array}$ & $\begin{array}{c}86.2^{\mathrm{d}} \\
(25)\end{array}$ & $\begin{array}{c}86.7^{e} \\
(26)\end{array}$ & $\begin{array}{l}97.0 \\
(32)\end{array}$ & $\begin{array}{c}21.9^{f} \\
(7)\end{array}$ & $\begin{array}{l}68.8^{f} \\
(22)\end{array}$ & $\begin{array}{c}79.3^{\mathrm{d}} \\
(23)\end{array}$ & $\begin{array}{c}76.7^{\mathrm{e}} \\
(23)\end{array}$ \\
\hline
\end{tabular}

Source: Prepared by the authors based on indicators extracted from the UNAIDS Global AIDS Monitoring database Integration of services includes both total and partial integration. 
TABLE 2. Core global and national indicators for TB/HIV, 2017

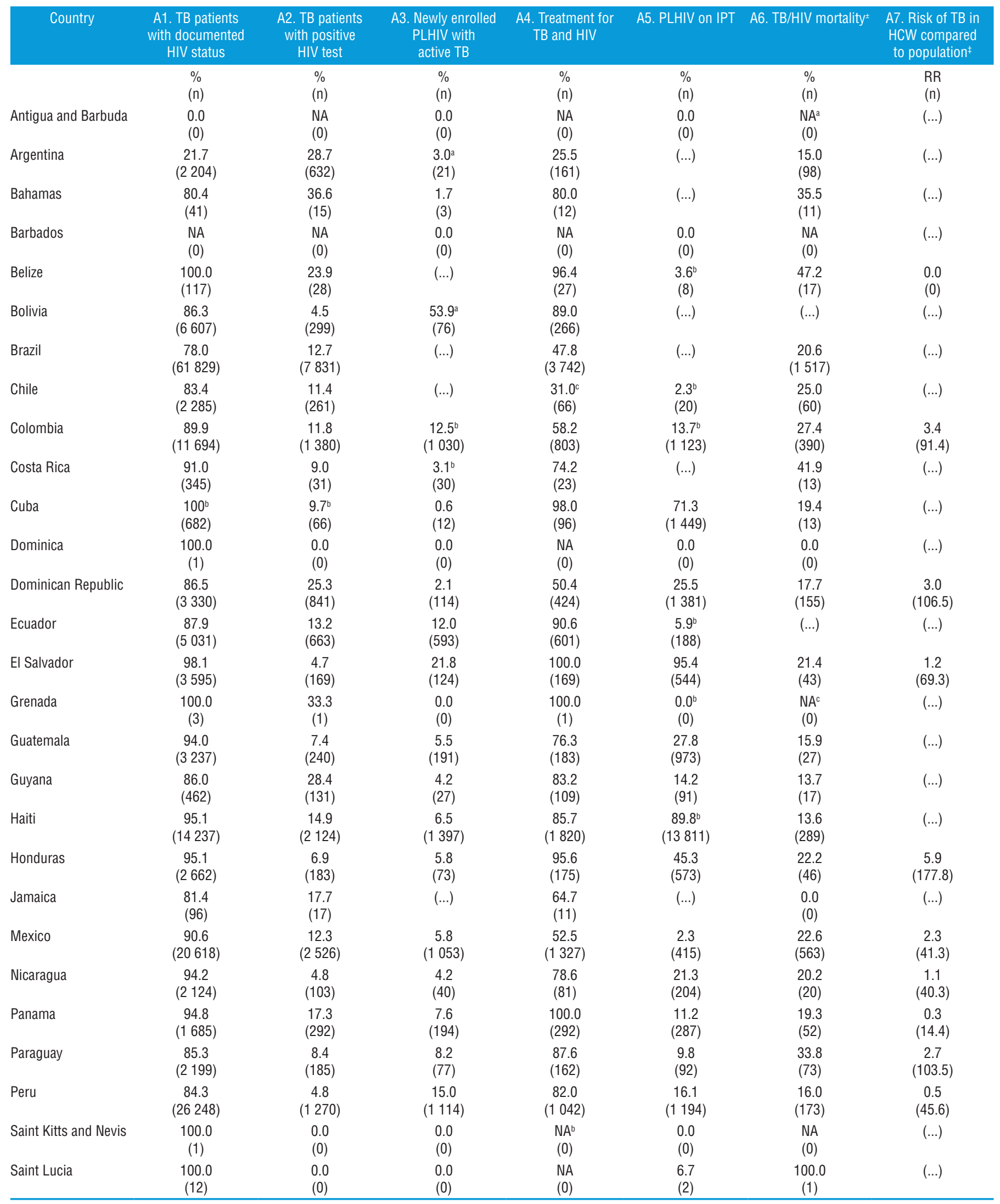


TABLE 2. Core global and national indicators for TB/HIV, 2017 (continued)

\begin{tabular}{|c|c|c|c|c|c|c|c|}
\hline Country & $\begin{array}{l}\text { A1. TB patients } \\
\text { with documented } \\
\text { HIV status }\end{array}$ & $\begin{array}{l}\text { A2. TB patients } \\
\text { with positive } \\
\text { HIV test }\end{array}$ & $\begin{array}{l}\text { A3. Newly enrolled } \\
\text { PLHIV with } \\
\text { active TB }\end{array}$ & $\begin{array}{l}\text { A4. Treatment for } \\
\text { TB and HIV }\end{array}$ & A5. PLHIV on IPT & A6. TB/HIV mortality ${ }^{ \pm}$ & $\begin{array}{l}\text { A7. Risk of TB in } \\
\text { HCW compared } \\
\text { to population }{ }^{\ddagger}\end{array}$ \\
\hline $\begin{array}{l}\text { Saint Vincent and the } \\
\text { Grenadines }\end{array}$ & $\begin{array}{l}0.0 \\
(0)\end{array}$ & $\begin{array}{l}N A \\
(0)\end{array}$ & $\begin{array}{l}N A^{b} \\
(0)\end{array}$ & $\begin{array}{l}\text { NA } \\
(0)\end{array}$ & $\begin{array}{l}6.3^{\circ} \\
(3)\end{array}$ & $\begin{array}{l}\text { NA } \\
(0)\end{array}$ & $(\ldots)$ \\
\hline Suriname & $\begin{array}{l}97.1 \\
(133)\end{array}$ & $\begin{array}{l}16.5 \\
(22)\end{array}$ & $\begin{array}{l}1.0 \\
(6)\end{array}$ & $\begin{array}{l}72.7 \\
(16)\end{array}$ & $(\ldots)$ & $\begin{array}{c}26.9 \\
(7)\end{array}$ & $(\ldots)$ \\
\hline Trinidad and Tobago & $\begin{array}{l}100.0 \\
(200)\end{array}$ & $\begin{array}{l}12.0 \\
(24)\end{array}$ & $\begin{array}{l}2.9 \\
(24)\end{array}$ & $\begin{array}{c}33.3 \\
(8)\end{array}$ & $\begin{array}{l}0.5 \\
(4)\end{array}$ & $\begin{array}{l}9.5 \\
(4)\end{array}$ & $(\ldots)$ \\
\hline Venezuela & $\begin{array}{c}60.0 \\
(6393)\end{array}$ & $\begin{array}{l}8.3 \\
(528)\end{array}$ & $(\ldots)$ & $\begin{array}{l}56.8 \\
(300)\end{array}$ & $(\ldots)$ & $\begin{array}{l}8.7 \\
(51)\end{array}$ & $\begin{array}{c}1.1 \\
(37.2)\end{array}$ \\
\hline All LAC & $\begin{array}{c}80.8 \\
(178948)\end{array}$ & $\begin{array}{c}11.2 \\
(19998)\end{array}$ & $\begin{array}{c}7.6 \\
(6 \quad 199)\end{array}$ & $\begin{array}{c}60.0 \\
(11991)\end{array}$ & $\begin{array}{c}30.7 \\
(22388)\end{array}$ & $\begin{array}{c}19.9 \\
(3679)\end{array}$ & $\begin{array}{c}1.5 \\
(50.6)\end{array}$ \\
\hline
\end{tabular}

Source: Prepared by the authors based on data extracted from WHO Tuberculosis database.

This information reflects the last available data point, which for most countries is 2017.

* Information from the 2016 TB/HIV outcomes cohort, unless otherwise specified

₹ Here the $\mathrm{n}$ represents the TB notification rate among health care workers (HCW) per 100000

RR Risk ratio

(n) Numerator
(...) Missing information

NA Result of dividing 0 by 0

Data from 2015

Data from 2016

Data from 2013

FIGURE 1. Time trend in LAC for indicators A1 "TB patients with documented HIV," A2 "TB patients with positive HIV test," and A4 “TB/HIV treatment," 2011-2017

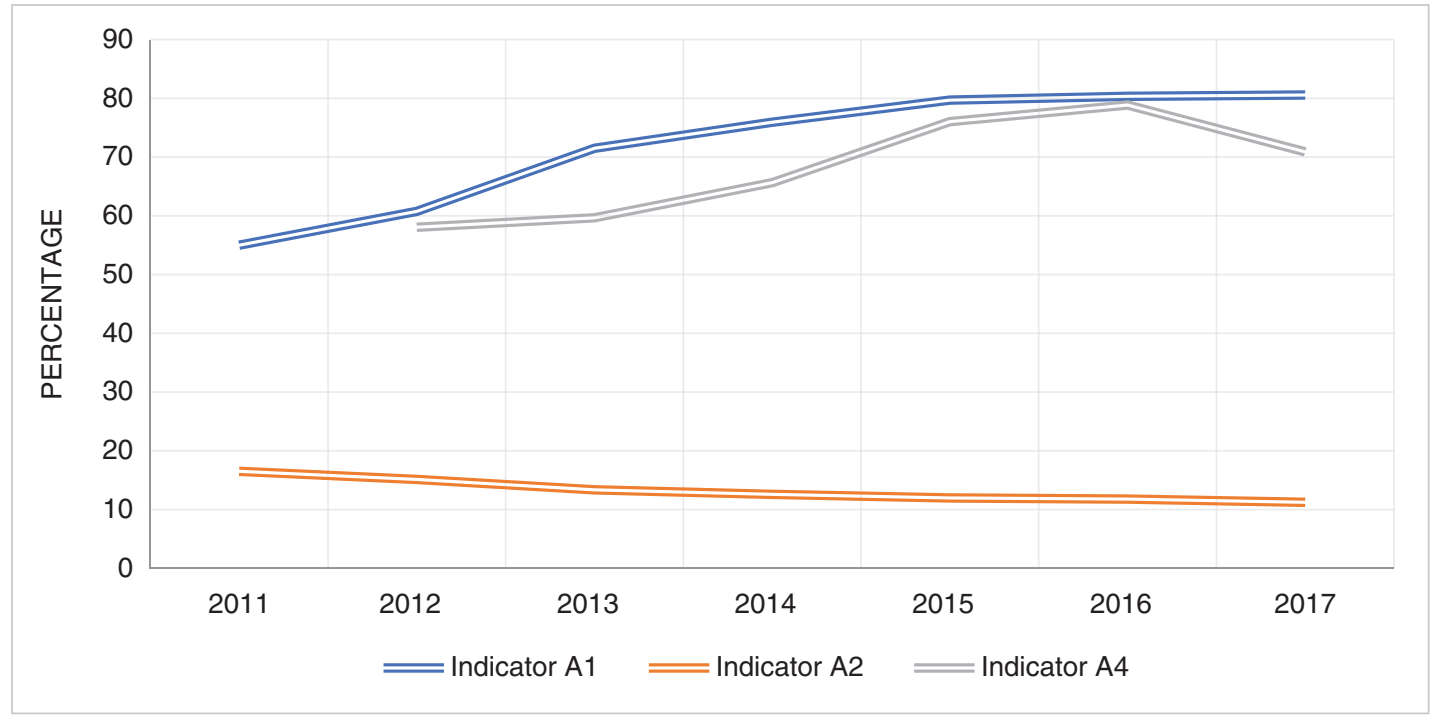

Source: Prepared by the authors based on data extracted from WHO Tuberculosis database.

For indicators A1 and A2, the figure excluded Antigua and Barbuda, Cuba, Nicaragua, Saint Kitts and Nevis, and Saint Vincent and the Grenadines. Indicator A4 excluded Argentina, Brazil, Chile, Jamaica, Nicaragua, Saint Kitts and Nevis, and Saint Vincent and the Grenadines; information from 2011 was excluded since several countries lacked data.

integration of HIV counseling and testing in TB services and TB screening in HIV services are considerably different between countries in the Caribbean and those in Latin America, at 76.9\% and $93.8 \%$, and $76.9 \%$ and $94.1 \%$, respectively.

In relation to the proportion of registered new and relapse TB patients with documented HIV-positive status (TB patients with positive HIV test, indicator A.2), the average for LAC was $11.2 \%$ (Table 2). It is worth noting that the Bahamas had the highest proportion in LAC, at $36.6 \%$. In respect to this indicator, a continuous decreasing trend was observed with a reduction of around 5\% between 2011 and 2017 (Figure 1).

Additionally, around $87 \%$ of countries in LAC reported having measures in place for integration of TB screening in HIV services (Table 1) and the proportion of PLHIV newly enrolled in HIV care with active TB in LAC (newly enrolled PLHIV with active TB, indicator A.3) was 7.6\% (Table 2). However, some countries were well above this average, such as El Salvador, for instance, with $21.8 \%$. 


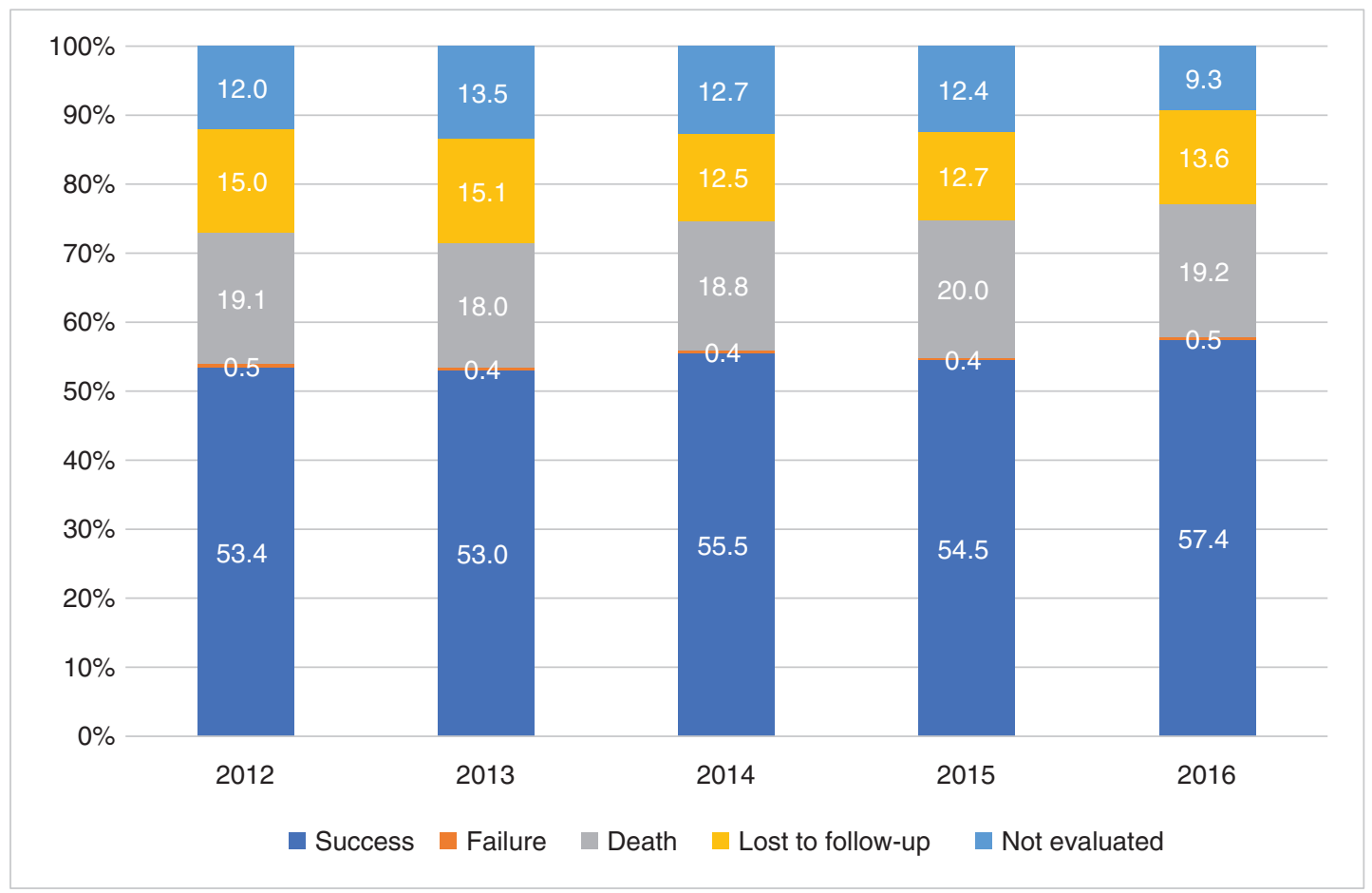

Source: Prepared by the authors based on data extracted from WHO Tuberculosis database.

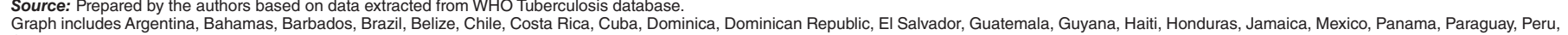
Suriname, Trinidad and Tobago, Uruguay, and Venezuela.

Regarding the proportion of HIV-positive new and relapse TB patients on antiretroviral therapy (ART) during TB treatment (treatment for TB and HIV, indicator A.4), the value for LAC was $60.0 \%$, although it varied significantly among countries (Table 2). For example, Belize, Cuba, El Salvador, Grenada, Honduras, and Panama reported a coverage above 95\%. On the other hand, Chile and Argentina reported a considerably lower TB/HIV treatment coverage, at $31.0 \%$ and $25.5 \%$, respectively. In relation to the time trend for this indicator in LAC, there was an overall increase of 20\% between 2012 and 2016, with a subsequent decline in 2017 (Figure 1). Of note, on service provision modalities, the proportion of countries with policies for TB treatment in ART settings was $68.8 \%$, in contrast to only $21.9 \%$ offering ART in TB settings. In addition, around $76.7 \%$ of countries had implemented different degrees of facility-based integrated TB and HIV service delivery (Table 1).

Furthermore, the proportion of PLHIV newly enrolled in care who started TB preventive therapy (i.e., PLHIV on isoniazid preventive therapy [IPT], indicator A.5) was only 30.7\% (Table 2). Yet, there were exceptions to this low figure, such as El Salvador, Haiti, and Cuba, at 95.4\%, 89.8\%, and $71.3 \%$, respectively.

Regarding mortality among HIV-positive new and relapse TB patients (TB/HIV cohort mortality, indicator A.6), the whole LAC region was at $19.9 \%$, which is very high considering that both diseases are preventable and treatable. Some countries were found to be well above the average, such as Belize (47.2\%) and Costa Rica (41.9\%), whereas others such as Haiti reported values below the average, with $13.6 \%$.

On the subject of the risk of TB among health care workers (HCW) relative to the general population (risk of TB in HCW compared to population, indicator A.7), only 12 countries in LAC (36.3\%) reported information. Still, based on the available data, the risk ratio (RR) for LAC was 1.5, although countries like Colombia and Honduras had values substantially above this average, at 3.4 and 5.9 (Table 2). Also, $79.3 \%$ of countries had established mechanisms for TB infection control in HIV health care settings (Table 1).

Finally, regarding treatment outcomes for the TB/HIV cohort in LAC between 2012 and 2016, a modest tendency toward improvement was found in the success rate, from $53.4 \%$ to $57.4 \%$ (Figure 2). At the same time, the percentage of cases lost to follow-up and not evaluated decreased from $15 \%$ to $13.6 \%$ and from $12 \%$ to $9.3 \%$, respectively. Notably, the trend for treatment failure and mortality remained stable throughout the five-year period, around $0.5 \%$ and $19 \%$, respectively.

\section{DISCUSSION}

The results of the review are discussed according to the three objectives in the WHO TB/HIV Policy, given its relevance, comprehensiveness, and clear approach.

1. "Establish and strengthen the mechanisms for delivering integrated TB and HIV services," where a coordinated policy of collaboration is the cornerstone of successful integration. The review found that there were some integrative mechanisms common to most countries, such as HIV testing in persons with TB. Although not universal, integration of counseling and screening for HIV in TB services, and of TB screening in HIV services, were found to be high (above 80\%). These findings highlight a common trend of fostering TB/HIV collaborative 
mechanisms and policies between TB and HIV programs at all levels across the region, where the decentralization of HIV care and treatment to the primary level continues to facilitate the process of gradually integrated service delivery. Noteworthy though, the study found a difference in TB and HIV integration policies between the Caribbean and Latin American regions, which may reflect the need to build up health system capacities, the still limited TB management at the primary level given the relatively low TB burden in some Caribbean countries (12), as well as possible social dynamics and cultural norms related to unfavorable perceptions of PLHIV and high-risk populations in this subregion (21). Overall, this finding signals the need for additional advocacy on integration and rights for people living with HIV and TB.

An additional point related to the first objective is ensuring proper monitoring and evaluation of TB/HIV. As the review showed, there were many instances where data were not available, bringing to the spotlight the need to improve information systems, as well as joint processes of data collection and analysis. A possible solution is the implementation and expansion of electronic health care records, which have been demonstrated to improve the accuracy and speed of general and TB/HIVrelated epidemiological surveillance across countries $(22,23)$.

2. "Reduce the burden of TB in PLHIV and initiate early ART." This objective comprises activities such as intensified case finding, IPT, and infection control for TB (these three activities are collectively known as the "three I's") (24). Among the specific sub-activities for intensified case finding, it is fundamental to assess the proportion of new reported PLHIV with active TB, a figure that was found to be $7.6 \%$, which is very close to the global TB/HIV prevalence in 2017, at $8 \%$ (25).

The second activity included under this objective is to initiate TB prevention with IPT. The review found that only around one-third of PLHIV had access to IPT, despite both its prominent role in reducing the incidence of active TB in PLHIV (26) and having established mechanisms across almost all countries in LAC supporting its implementation, as evidenced in the results section. Since only a fraction of PLHIV have access to IPT, alternative options with simplified/shorter regimens could be implemented, such as rifapentine plus isoniazid (27).

The third activity under the second objective is to ensure control of TB infection in health care facilities and congregate settings. The indicator "TB infection control in HIV health care settings" showed that the majority of countries (79.3\%) have a policy aimed at reducing TB transmission at institutional level. This result contrasts with the actual assessment of TB prevalence in HCW, which was available for only few countries. Despite the scarcity of data, it can be said that the relative risk of TB among HCW in LAC was 1.5 times higher than in the general population. This result stresses the importance of practical measures for TB infection control in health care settings to prevent its nosocomial transmission, which can lead to additional resistance and mortality (28), especially among highly susceptible population such as PLHIV (29). These measures could include the separation of those with presumptive active TB in waiting rooms and the use of surgical masks by patients (28).

3. "Reduce the burden of HIV in patients with presumptive and diagnosed $\mathrm{TB}$, " which includes assessing the proportion of registered new and relapse TB patients with documented HIV status. Unfortunately, this indicator has not reached full coverage in the region $(80.8 \%)$ but is still above the world average
$(60 \%)(12)$. The results also revealed an overall rising trend for this indicator from 2011 onward, corresponding to a worldwide tendency (12), although the last three years have evidenced stagnation. The initial positive trend is likely the result of the increasing uptake of international guidelines, such as extended rapid testing by trained lay providers, testing in serodiscordant couples and pregnant women, and community-based testing in key populations $(30,31)$. The halt, however, could be secondary to deficient data recording, and laboratory capacities. Yet, it has to be stressed that this indicator is of substantial significance since it allows the identification of the coinfection, permitting further follow-up, treatment, and the crafting of future preventive strategies.

Another notable finding was the small but progressive reduction in the proportion of TB patients with HIV-positive status from 2011 to 2017, which is in accordance with worldwide trends (3). Despite this tendency, it is important to highlight that a significant diagnostic gap remains between notified cases (around 20 000) and the best estimates from the last Global Tuberculosis Report (about 30 000) (12). This finding underlines the need to improve TB/HIV coinfection diagnosis through strategies like identification and testing of key populations; strengthen both HIV testing and counselling in all presumptive or diagnosed TB patients and surveillance of active TB among PLHIV; build advocacy, communication, and education policies on the topic; and develop better health care data systems (11).

Another indicator linked to this objective is the proportion of TB/HIV patients on ART during TB treatment. The review found that $60 \%$ of this group received therapy for both conditions in 2017, and although the time trend illustrated an overall tendency to increase over the years, the figure declined in 2017. This result is concomitant with the stabilization of HIV screening coverage and along with it may provide an explanation of why the mortality in the TB/HIV cohort has not changed during recent years. This finding deserves further exploration, as well as joint efforts from national and local public health authorities, health care providers, pharmaceutical companies, and civil society to grant timely and adequate ART and TB treatment through securing affordable prices, preventing outof-stock situations, and preparing health care institutions and training human resources in identifying and treating HIV and TB. Additionally, there was a tendency to have a rather low percentage of TB and HIV treatment coverage in countries that lacked full integration of ART and anti-TB drugs provision (e.g., Argentina, Brazil, and Chile). This finding may suggest that integration of TB/HIV treatment at all levels of the system may contribute to a broader TB/HIV treatment coverage, which in turn reduces the morbidity and mortality of TB in PLHIV, and vice versa (32). It is noteworthy that this indicator is measured as ART in coinfected people diagnosed with TB as a proxy, given its availability in the source databases and broader reporting from countries, with the assumption that all people diagnosed with TB are receiving TB treatment. This finding also highlights the lack of integration and comprehensiveness in information systems for two diseases that are closely interrelated.

Data on the quality of treatment were based on the TB treatment cohorts for TB/HIV cases. These results showed that the treatment success during the period 2012-2016 had a small tendency toward improvement, due to the decrease of both the lost to follow-up and not-evaluated groups. Still, the last data point showed that LAC was at $57.4 \%$, which is below the world 
average of $77.0 \%$ (12). Regarding mortality in this cohort, the values for the same time period appear stable at around $20 \%$. This result contrasts with the progressive reduction of both TB mortality (13) and all AIDS-related mortality during recent years (3). This situation could be explained by factors such as poor adherence to treatment secondary to social and biological factors (33), and the absence of a timely coinfection diagnosis, thus preventing an early access to treatment (34). In general, the cohort outcomes call for more integration and implementation of TB/HIV collaborative activities, a strategy to refine diagnosis on HIV comorbidities, as well as actions that revise the service delivery model, quality, and conditions in which therapy is provided.

\section{Limitations}

One of the main shortcomings of this review is the absence of data, which, in consequence, left a blind spot on some of the TB/HIV epidemiological and programmatic indicators. Additionally, this situation generated a bias in relation to the representativeness of the aggregated results through skewing these values in favor of those countries with available information. Moreover, the aggregated means for any given year (usually 2017) illustrated in the cross-sectional description were only proxies, since some of the data points were taken from different years.

\section{Conclusions}

Establishing collaborative mechanisms for a successful and comprehensive management of TB/HIV coinfection is one of the pivotal strategies for tackling the TB and HIV epidemics
$(8,9,35)$. Findings such as a lack of data that hinders proper assessment and follow-up of the TB/HIV epidemiological situation, insufficient legislation on TB/HIV services and their integration, or limited institutional accountability that prevents their actual implementation, have deleterious consequences for both the patient and the system. These drawbacks, for instance, may increase health care costs, delay diagnosis and access to treatment, favor loss to follow-up, and ultimately increase morbidity and mortality. In response, TB and HIV programs at all levels, health care institutions, practitioners working with people living with HIV and TB, and civil society should strive for closer collaboration and full integration of services-focusing on building up health system strengthening, governance, human resources, monitoring and evaluation, and when present, tackling social stigma and institutional bias-so that it is possible to ensure the highest attainable success rates, progressive reduction, and eventual cessation of the burden inflicted by TB/HIV coinfection.

Author contributions. GR and RL conceived the research topic. PA revised the computations and guided the manuscript's structure. RM conducted the data analysis and wrote the manuscript. GR, RL, and PA provided substantial feedback on the contents and reviewed the document for technical accuracy. All authors reviewed and approved the final version.

Conflicts of interest. None declared.

Disclaimer. Authors hold sole responsibility for the views expressed in the manuscript, which may not necessarily reflect the opinion or policy of the RPSP/PAJPH and/or the Pan American Health Organization.

\section{REFERENCES}

1. World Health Organization. Tuberculosis and HIV - Factsheet on HIV-associated TB. WHO [Online]. Geneva: WHO. [Cited 2018 Nov 11]. Available from: https://www.who.int/hiv/topics/tb/en/.

2. UNAIDS. Factsheet - 2018. UNAIDS [Online]. Geneva:UNAIDS, 2018. [Cited 2018 Nov 25]. Available from: http://www.unaids. org/en/resources/fact-sheet.

3. UNAIDS. MILES TO GO - Global AIDS update 2018. UNAIDS [Online]. Geneva:UNAIDS, 2018. [Cited 2018 Nov 21]. Available from: https://www.unaids.org/sites/default/files/media_asset/ miles-to-go_en.pdf.

4. World Health Organization. Health statistics and information systems-Disease burden and mortality estimates. WHO [Online]. Geneva:WHO. [Cited 2018 Nov 21]. Available from: https://www. who.int/healthinfo/global_burden_disease/estimates/en/index1. $\mathrm{html}$.

5. McDonald E, Smith-Palmer A, Wallace LA, Blatchford O. Risk factors for TB and HIV coinfection in Scotland, 2001 to 2010. Euro Surveill. 2015;20(11).

6. Méda ZC, Sombié I, Sanon OW, Maré D, Morisky DE, Chen YM. Risk factors of tuberculosis infection among HIV/AIDS patients in Burkina Faso. AIDS Res Hum Retroviruses. 2013;29(7):1045-55.

7. Kwan CK, Ernst JD. HIV and tuberculosis: a deadly human syndemic. Clin Microbiol Rev. 2011;24(2):351-76.

8. World Health Organization. End TB Strategy. WHO [Online]. Geneva:WHO, 2015. [Cited 2018 Nov 21]. Available from: https:/ / www. who.int/tb/post2015_strategy/en/.

9. World Health Organization. GLOBAL HEALTH SECTOR STRATEGY ON HIV 2016-2021. WHO [Online]. Geneva:WHO, 2016.
[Cited 2018 Nov 25]. Available from: https://apps.who.int/iris/ bitstream/handle/10665/246178/WHO-HIV-2016.05-eng.pdf

10. United Nations. UN General Assembly high-level meeting on TB. World Health Organization - Tuberculosis [Online]. New York: UN, 2018. [Cited 2018 Dec 10]. Available from: https://www.who.int/ $\mathrm{tb}$ /features_archive/UNGA-adopts-TB-declaration/en/.

11. World Health Organization. WHO policy on collaborative TB/HIV activities. WHO [Online]. Geneva:WHO, 2012. [Cited 2018 Dec 10]. Available from: https://www.who.int/tb/publications/2012/ tb_hiv_policy_9789241503006/en/

12. World Health Organization. Global Tuberculosis Report 2018. WHO [Online]. Geneva:WHO, 2018. [Cited 2018 Dec 15]. Available from: http://apps.who.int/medicinedocs/documents/s23553en/ s23553en.pdf

13. Pan American Health Organization. Tuberculosis in The Americas 2018. PAHO [Online]. Washington D.C.:PAHO, 2018. [Cited 2018 Nov 15]. Available from: http://iris.paho.org/xmlui/bitstream/ handle $/ 123456789 / 49510 /$ PAHOCDE18036_eng? sequence= $1 \&$ isAllowed $=y$

14. Pan American Health Organization. Current Status on the implementation of TB-HIV collaborative activities in the Americas. PAHO [Online]. Washington D.C.:PAHO, 2012. [Cited 2019 Dec 10]. Available from: http:/ /iris.paho.org/xmlui/bitstream/handle/123456789/6084/ current $\% 20$ status $\% 20$ TB\%20HIV\%20Americas\%202012.pdf? sequence $=1 \&$ is Allowed $=\mathrm{y}$

15. Krauss MR, Harris DR, Abreu T, Ferreira FG, Ruz NP, Worrell C, et al. Tuberculosis in HIV-infected infants, children, and adolescents in Latin America. Braz J Infect Dis. 2015;19(1):23-9. 
16. Podlekareva DN, Efsen AM, Schultze A, Post FA, Skrahina AM, Panteleev A, et al. Tuberculosis-related mortality in people living with HIV in Europe and Latin America: an international cohort study. Lancet HIV. 2016;3(3):e120-31.

17. WHO \& UNAIDS. A guide to monitoring and evaluation for collaborative TB/HIV activities, 2015 revision. WHO [Online]. Geneva:WHO, 2015. [Cited 2019 Feb 20]. Available from: https://apps.who. int/iris/bitstream/handle/10665/150627/9789241508278_eng. pdf?sequence $=1$

18. UNAIDS. Global AIDS Monitoring 2018. UNAIDS [Online]. Geneva:UNAIDS, 2017. [Cited 2018 Dec 15]. Available from: https:/ / www.unaids.org/sites / default/files/media_asset/ 2017-Global-AIDS-Monitoring_en.pdf

19. World Health Organization. WHO - Tuberculosis (TB). WHO [Online]. Geneva:WHO. [Cited: 2018 Sep 28]. Available from: http://www.who.int/tb/country/data/download/en/.

20. UNAIDS. Global AIDS Monitoring (GAM) / Laws and Policies Analytics. UNAIDS [Online]. Geneva:UNAIDS. [Cited: 2018 Sep 25]. Available from: http:/ /lawsandpolicies.unaids.org/topics

21. Rutledge SE, Abell N, Padmore J, McCann TJ. AIDS stigma in health services in the Eastern Caribbean. Sociol Health Illn. 2009;31(1):17-34.

22. Birkhead GS, Klompas M, Shah NR. Uses of electronic health records for public health surveillance to advance public health. Annu Rev Public Health. 2015;36:345-59.

23. Fraser HS, Biondich P, Moodley D, Choi S, Mamlin BW, Szolovits P. Implementing electronic medical record systems in developing countries. Inform Prim Care. 2005;13(2):83-95.

24. World Health Organization. WHO Three I's Meeting. WHO [Online]. Geneva:WHO, 2008. [Cited 2019 Jan 20]. Available from: https:// www.who.int/hiv/pub/meetingreports/WHO_3Is_meeting_ report.pdf

25. World Health Organization. WHO-TB/HIV factsheet. WHO [Online]. Geneva:WHO, 2018. [Cited 2019 Jul 22]. Available from: https://www.who.int/tb/areas-of-work/tb-hiv/tbhiv_factsheet. pdf?ua $=1$.

26. Lawn SD, Wood R, De Cock KM, Kranzer K, Lewis JJ, Churchyard GJ. Antiretrovirals and isoniazid preventive therapy in the prevention of HIV-associated tuberculosis in settings with limited health-care resources. Lancet Infect Dis. 2010;10(7):489-98.

27. World Health Organization. Tuberculosis - WHO guidelines on the management of latent tuberculosis infection launched today. WHO
[Online]. Geneva:WHO, 2014. [Cited 2019 Jul 15]. Available from: https://www.who.int/tb/features_archive/LTBI/en/.

28. World Health Organization. WHO policy on TB infection control in health-care facilities, congregate settings and households. WHO [Online]. Geneva:WHO, 2009. [Cited 2018 Nov 16]. Available from: http://apps.who.int/iris/bitstream/handle/10665/44148/ 9789241598323_eng.pdf?sequence $=1$.

29. Caminero JA. Multidrug-resistant tuberculosis: epidemiology, risk factors and case finding. Int J Tuberc Lung Dis. 2010;14(4):382-90

30. UNAIDS. 90-90-90. An ambitious treatment target to help end the AIDS epidemic. UNAIDS [Online]. Geneva:UNAIDS, 2014. [Cited 2018 Nov 16]. Available from: https://www.unaids.org/sites/default/ files/media_asset/90-90-90_en.pdf

31. World Health Organization. Consolidated guidelines on HIV testing services. WHO [Online]. Geneve:WHO, 2015. [Cited 2019 Feb 15]. Available from: https://apps.who.int/iris/bitstream/handle/ 10665/179870/9789241508926_eng.pdf?sequence $=1$

32. Kwara A, Flanigan TP, Carter EJ. Highly active antiretroviral therapy (HAART) in adults with tuberculosis: current status. Int J Tuberc Lung Dis. 2005;9(3):248-57.

33. Munro SA, Lewin SA, Smith HJ, Engel ME, Fretheim A, Volmink J. Patient adherence to tuberculosis treatment: a systematic review of qualitative research. PLoS Med. 2007;4(7):e238.

34. Manosuthi W, Chottanapand S, Thongyen S, Chaovavanich A, Sungkanuparph S. Survival rate and risk factors of mortality among $\mathrm{HIV}$ / tuberculosis-coinfected patients with and without antiretroviral therapy. J Acquir Immune Defic Syndr. 2006;43(1):42-6.

35. United Nations. United Nations - Sustainable Development Goals. Sustainable Development Goals [Online]. New York:UN, 2015. [Cited: 2018 Dec 12]. Available from: http://www.un.org/en/ development/desa/population/migration/generalassembly/ docs/globalcompact/A_RES_70_1_E.pdf.

Manuscript received on 13 November 2019. Revised version accepted for publication on 25 February 2020.

\section{Coinfección por tuberculosis y VIH, y actividades de colaboración relacionadas en América Latina y el Caribe}

RESUMEN

Palabras clave
Objetivo. Informar sobre las tendencias epidemiológicas más recientes y la respuesta programática integrada frente a la coinfección por tuberculosis (TB) y VIH en América Latina y el Caribe.

Métodos. En una revisión descriptiva se analizaron los indicadores más pertinentes sobre la coinfección por TB y VIH en 33 países de América Latina y el Caribe, por medio de un enfoque transversal y de tendencias en el tiempo. Los datos se obtuvieron de bases de datos disponibles públicamente y se analizaron mediante proporciones sencillas, medias ponderadas y cociente de riesgos.

Resultados. En el 2017, en América Latina y el Caribe se sometió a 80,8\% de los pacientes con TB a un tamizaje activo del VIH, lo que representó un aumento de 25,6\% entre el 2011 y el 2017. En ese mismo año, la proporción de pacientes con TB e infección por el VIH fue de 11,2\%, lo cual demuestra una pequeña reducción, aunque progresiva, de 5\% desde el 2011. El suministro de tratamiento antirretroviral y de fármacos contra la TB a los pacientes con la coinfección en el 2017 fue del 60\%. Solo un tercio de las personas con VIH tuvieron acceso al tratamiento preventivo con isoniacida. En términos generales, la tasa de mortalidad de las personas con coinfección por TB y VIH no ha cambiado desde el 2012, y ha permanecido en torno al $20 \%$.

Conclusiones. Se está aumentando la escala de las actividades de colaboración entre los servicios de TB y VIH en América Latina y el Caribe, como el tratamiento de base para abordar los casos de coinfección, y algunos indicadores muestran una tendencia positiva. No obstante, nuestra revisión muestra la necesidad de seguir fortaleciendo la integración de la prestación de servicios, las actividades conjuntas de seguimiento y evaluación, y la comprobación de la calidad de los datos.

VIH; tuberculosis; coinfección; política de salud; América Latina. 


\section{Coinfecção por tuberculose e HIV e atividades colaborativas relacionadas na América Latina e Caribe}

RESUMO Objetivo. Informar sobre as últimas tendências epidemiológicas e a resposta programática integrada à coinfecção por tuberculose (TB) e HIV na América Latina e Caribe (ALC).

Métodos. Uma revisão descritiva analisou os indicadores mais relevantes sobre a coinfecção por TB/HIV em 33 países da ALC, usando uma abordagem transversal e de tendências temporais. Os dados foram obtidos em bases de dados disponíveis publicamente e analisados através de proporções simples, médias ponderadas e razões de risco.

Resultados. Na ALC, em 2017, 80,8\% dos pacientes com TB realizaram o rastreamento ativo para HIV, o que representou um aumento de 25,6\% entre 2011 e 2017. No mesmo ano, a proporção de pacientes com TB com status HIV positivo foi de 11,2\%, demonstrando uma pequena redução progressiva de 5\% desde 2011. Em 2017, a oferta de terapia antirretroviral e medicação anti-TB aos pacientes coinfectados por TB/HIV foi de $60 \%$. Somente um terço das pessoas que vivem com HIV teve acesso à terapia preventiva com isoniazida. A mortalidade geral na coorte coinfectada por TB/HIV não mudou desde 2012, oscilando em torno de $20 \%$.

Conclusões. As atividades colaborativas para TB/HIV, que são a espinha dorsal para combater esta coinfecção, estão sendo ampliadas na ALC, e alguns indicadores mostram uma tendência positiva; no entanto, a nossa revisão destaca a necessidade de continuar fortalecendo a integração da prestação de serviços, as atividades conjuntas de monitoramento e avaliação e a qualidade dos dados.

Palavras-chave HIV; tuberculose; coinfecção; política da saúde; América Latina. 